\title{
Student Engagement and Leadership of the Transition Planning Process
}

Career Development and Transition for Exceptional Individuals 36(I) 43-50

(C) Hammill Institute on Disabilities 2013

Reprints and permissions:

sagepub.com/journalsPermissions.nav DOI: $10.1177 / 2165143413476545$ cdtei.sagepub.com

@SAGE

\author{
James E. Martin, PhD' and Kendra Williams-Diehm, PhD'
}

\begin{abstract}
The Council for Exceptional Children's Division on Career Development and Transition (DCDT) has been a longstanding leader and advocate in the field of secondary education for students with disabilities. This paper traces the history of student engagement in transition planning primarily through the lens of DCDT's journal Career Development for Exceptional Individuals, now known as Career Development and Transition for Exceptional Individuals. Student engagement in the transition planning process implies meaningful student participation in Individualized Education Plan (IEP) meetings, including both student leadership of IEP meetings and presenting IEP results during meetings, student engagement in the transition planning process, participation in and understanding of transition assessment results, and the attainment of annual IEP transition goals. The idea of student engagement in the transition planning process was initially delivered in a larger context, and then across the years, the topic became the primary focus of specific articles. We trace this development and conclude by speculating where student engagement in transition planning will go in the future. Suggestions are offered for both research and practice.
\end{abstract}

\section{Keywords}

IEP development, self-determination, student-led planning, goal attainment

During the past 35 years, Career Development for Exceptional Individuals, now known as Career Development and Transition for Exceptional Individuals (CDTEI), has emerged as a progressive voice for secondary to postsecondary transition education and services for students with disabilities. Since its 1st year of publication in 1978, CDTEI has called for secondary students to be engaged in the transition planning and education process, and as the journal reports, more secondary-age students are taking an active role in planning their future and being directly engaged in the transition education process. However, the work is far from over, as too many high school students with Individualized Education Plans (IEPs) are not taught basic selfdetermination skills nor provided the opportunity to actively participate or lead their IEP transition planning process (Rusch, Hughes, Agran, Martin, \& Johnson, 2009). In addition, too many students with IEPs do not graduate or successfully transition from school to postschool employment or education (Trainor, Lindstrom, Simon-Burroughs, Martin, \& Sorrells, 2008).

In 1987, the idea of self-management strategies that would enable students to achieve successful employment outcomes and generalization of learned skills emerged in an issue of CDTEI (Agran, 1987). During the same year, the concept of Adaptability Instruction emerged from the business and self-management literature as a means to teach individuals with disabilities a goal-setting and adjustment process to adapt to changing school and worksite demands (Mithaug, Martin, \& Agran, 1987). The generalization of the Adaptability Instruction model to transition was significantly reinforced in 1988 when the U.S. Department of Education's Office of Special Education and Rehabilitation Services funded 26 model demonstration projects to develop self-determination instructional materials to improve the transition outcomes of youth with disabilities (Field, 1996; Wehmeyer, Palmer, Agran, Mithaug, \& Martin, 2000). These projects and their resulting teaching materials led to self-determination becoming a major instructional focus of transition education, and now the field strongly encourages student engagement in the transition planning process as a means of learning and practicing self-determination skills.

\footnotetext{
'University of Oklahoma, Norman, USA

Corresponding Author:

James E. Martin, Zarrow Center for Learning Enrichment, University of Oklahoma, 338 Cate Center Drive, Room 190, Norman, OK 73019-217I, USA.

Email: jemartin@ou.edu
} 
One reason that educators embraced self-determination is that transition education provides an ideal opportunity for students to both learn and practice self-determination skills (Martin, Marshall, \& Maxson, 1993). Although various self-determination definitions exist, the field generally agrees that self-determination encompasses students' understanding of their interests, strengths, and weaknesses, using this information to establish and attain their goals, and making needed adjustments to attain their goals (Field, Martin, Miller, Ward, \& Wehmeyer, 1998a).

When the instructional focus of self-determination practices was combined with the first definition of transition services in the Individuals With Disabilities Education Act of 1990 (IDEA), the importance of student needs and preferences in determining transition goals was ensured. It was now required that students be invited to participate in transition planning IEP meetings. The result was that student involvement in the transition planning and education process became a foundational transition education practice, and active student participation in transition planning quickly became the "best" transition education practice (Halpern, 1994).

This article will discuss the concept of student engagement and leadership of the transition education process by examining what CDTEI authors said and discovered over the past 35 years. First, we will explore student engagement in the transition assessment process. Next, we will examine student engagement and leadership of the IEP transition meeting where transition planning takes place. Third, we will delve into the emerging area of student attainment of their annual transition goals. Last, we will offer recommendations to ensure that student engagement in the transition planning process continues in the future.

\section{Student Engagement in Transition Assessment}

The concept of promoting student engagement in the transition assessment process had roots back to the beginning of the journal. Sitlington and Wimmer (1978) advised special educators to teach students to use assessment information so that students can make realistic choices and decisions. D. R. Johnson (1979) advocated using ongoing assessment of interests and abilities to ensure that students have "a better opportunity to share equally in the process of career development" (p. 47). Hill (1983) recommended that students be asked to determine their opinion about the strengths and weaknesses of the assessment process and tools used. Roberts, Doty, Santleben, and Tang (1983) advised educators to assist students in understanding their vocational interests and aptitudes. Wehmeyer (1993) determined that adolescents with disabilities lack career decision-making skills, clearly demonstrating the importance of the aforementioned skills. He recommended that educational programs provide instruction so that students can become self-determined to "assume greater control over and responsibility for educational and transition planning and be involved in selecting and prioritizing goals and objectives" (Wehmeyer, 1993, p. 144).

In a Division on Career Development and Transition (DCDT) position paper, Halpern (1994) indicated that typical assessment processes limit the "opportunities for people with disabilities to take charge and ownership of their own evaluations" (p. 118). Instead, the transition assessment process must actively engage students, and educators must teach the meaning of the assessment results to students so they can select appropriate postschool goals. Sitlington (1996) echoed this view while calling for educators to involve students with disabilities in the design, implementation, and interpretation of transition assessment results. Student involvement in the transition assessment process will increase their understanding of "strengths, needs, preferences, and interests and how these relate to work and careers, postsecondary education, independent living, community activities, and personal and social relationships" (Sitlington, Neubert, \& Leconte, 1997, p. 72).

In a subsequent DCDT position paper, Field, Martin, Miller, Ward, and Wehmeyer (1998b) indicated that the transition assessment process provides an excellent instructional opportunity to teach and practice self-determination skills, and that student engagement in transition assessment must occur at multiple levels. This includes student involvement in deciding what needs to be assessed, gathering data through interviews of significant others, and using results of the assessment process to determine postsecondary and annual transition goals. As a timely reminder of the longlasting CDTEI call to engage students in the transition assessment process, Morningstar and Liss (2008) recently suggested "students should take the lead in gathering data, interpreting results, and creating goals" as this allows them to "participate in assessment planning; to advocate for themselves in interpreting results; and in planning for, and directing, their individualized transition services, goals, and needs" (p. 53).

\section{Student Engagement in Transition Planning}

Conceptually, the need to engage students in transition planning first emerged in CDTEI writings, followed by the development of instructional materials and practical demonstrations, then research, and finally summaries of the completed research. We will trace the development of each step.

\section{Conceptual Emergence}

In 1983, Roberts et al. (1983) suggested that students become involved in their IEP meetings. Steere, Pancsofar, 
Wood, and Hecimovic (1990) indicated that students need ample knowledge to facilitate their informed participation in the transition planning process and that students with the most severe disabilities should be included in "some facet of the transition planning process" (p. 145). J. R. Johnson and Rusch (1993) recommended that future research examine how to encourage student participation and involvement in the transition process, and that future research needs to determine the risks and outcomes associated with not involving students in the transition planning process. Martin et al. (1993) indicated that to facilitate the transition from high school to further education or employment, students need to learn to self-manage their IEP meetings by first participating, then learning to develop the IEP, and finally, managing or leading the IEP process.

Halpern (1994) summarized the emerging student involvement concepts and concluded that students should be encouraged to the best of their abilities to become actively involved in the transition planning process. He added that student selfevaluation, student identification of postschool goals, and student choice of high school experiences would lead to enhanced student self-determination. Foreshadowing today's research results, Halpern postulated that educator-directed transition planning meetings would limit student engagement in transition planning opportunities.

Field (1996) envisioned a future where all high school students will have individualized transition plans containing self-selected goals based on their understanding of students' strengths and needs. Ianacone and Kochhar (1996) indicated that active student involvement in the transition planning meetings would help teach students self-determination skills, and this process would be a transformative transition education theme. From a study of due process hearings, Etscheidt (2006) determined that districts need to "ensure meaningful student involvement in transition planning" ( $p$. 36 ), and those that do not face forced corrective action. Rusch et al. (2009) indicated that transition education must involve teaching middle school students to learn to direct their own education planning process and that this instructional focus continues through high school with students receiving support and having the opportunity to lead their own IEP transition planning meetings.

\section{Development of Instructional Processes and Materials}

Martin et al. (1993) presented a longitudinal scheme to implement student engagement in transition planning. During the elementary years, students will attend IEP meetings as observers and answer questions; in middle school, students will learn to actively participate in their IEP meetings; and in high school, students will lead their IEP meetings and manage the IEP transition process. However,
Martin et al. indicated that the lack of effective lesson materials and strategies to teach students the skills needed for effective student engagement in the IEP transition planning process impeded this educational advancement as a means to teach self-determination skills. Since then, several methods, strategies, and lesson packages have been developed to teach students to become actively involved in their transition IEP meetings, and many of these have been described in the CDTEI journal.

Wehmeyer and Lawrence (1995) developed and piloted one of the first instructional programs to actively participate in their transition IEP planning discussions titled Whose Future Is It Anyway? Wehmeyer, Palmer, Lee, Williams-Diehm, and Shogren (2011) found that the Whose Future Is It Anyway? lesson package increased students' self-determination skills and transition knowledge. Palmer, Wehmeyer, Shogren, Williams-Diehm, and Soukup (2012) combined Whose Future Is It Anyway? with the SelfDetermined Learning Model of Instruction (Wehmeyer et al., 2000) as a means to increase active student participation in their transition planning process and self-determination scores.

In a self-determination position paper, Field et al. (1998a) stated that students can easily be engaged in the IEP transition planning process by inviting friends and team members to the IEP meeting, taking the seat at the head of the IEP planning table, and leading the actual IEP meeting with support provided by educators, parents, or friends. L. E. Powers et al. (2001) determined the effectiveness of the Take Charge for the Future lessons to increase students' involvement in transition planning activities and actual participation in transition planning meetings. Allen, Smith, Test, Flowers, and Wood (2001) taught a modified version of the Self-Directed IEP (Martin, Marshall, Maxson, \& Jerman, 1996) lesson package and significantly increased the IEP participation skills of students with moderate intellectual disabilities. Mason, McGahee-Kovac, Johnson, and Stillerman (2002) used an instructional program titled Student-Led IEPs: A Guide for Student Involvement to increase high school students' participation in their IEP meetings. Konrad and Test (2004) taught middle school students with high incidence disabilities to write their IEP document.

Woods, Sylvester, and Martin (2010) demonstrated that the Student-Directed Transition Planning lessons increased students' knowledge of the information they need to understand and share about themselves during the transition planning discussion of an IEP meeting, and also increased students' self-efficacy statements regarding participation in the transition discussions of their IEP meetings. After instruction, students indicated that they could talk about their disability, their postschool employment, their education, their independent living goals, and the course of study needed to attain their postsecondary goals. Martin, Van Dycke, D'Ottavio, and Nickerson (2007) developed and 
recommended that students use the student-directed summary of performance template to prepare for their annual IEP transition meetings and to provide students a script that can be used to engage in all facets of transition planning.

\section{Research}

Lehmann, Bassett, Sands, Spencer, and Gliner (1999) identified student, school, and family factors that individually and collectively predicted student participation in the transition planning process. The strongest predictors for student involvement in the transition planning process included (a) students' goal-attainment skills, (b) students' job competence, (c) democratic and noncontrolling family interactions, (d) family valuing enhanced student engagement, and (e) students attending and receiving special education services in general education classes.

More recently, Morningstar et al. (2010) found that the greater students perceived their families' involvement in their transition process, and the more they received instruction on how to become involved in the IEP transition planning process, the greater students' participation in the IEP transition planning process. The importance of self-determination instruction was again demonstrated with special populations, including girls (Coutinho, Oswald, \& Best, 2006), culturally and linguistically diverse students and their families (Griffin, 2011; Valenzuela \& Martin, 2005), and students with chronic health care needs (Repetto et al., 2012).

Research has also examined student attendance and participation in the IEP process, and has revealed varying levels of attendance and participation (Cobb \& Alwell, 2009; Landmark, Ju, \& Zhang, 2010; Martin, Greene, \& Borland, 2004; K. M. Powers et al., 2005; Repetto, Webb, Garvan, \& Washington, 2002; Rusch et al., 2009; Weidenthal \& Kochhar-Bryant, 2007; Zhang, Ivester, Chen, \& Katsiyannis, 2005). The positive impact on person-centered planning on the IEP process has also been demonstrated (Flannery et al., 2000).

Summaries of Research. More recently, several articles have reported on self-determination and student-focused planning. These articles support student-focused planning as a means to increase participation in transition planning and subsequently to improve student involvement and the transition outcomes of students with disabilities (Cobb \& Alwell, 2009; Cobb, Lehmann, Newman-Gonchar, \& Alwell, 2009; Griffin, 2011). Likewise, Test et al. (2009) determined that two lesson packages, the Self-Directed IEP (Martin et al., 1996) and the Self-Advocacy Strategy (field tested under the original title of The Education Planning Strategy by Van Reusen, Bos, Schumaker, \& Deshler, 1987), have a moderate level of evidence supporting their effectiveness.

\section{Student Engagement in Attaining Annual Transition Goals}

Once students become actively engaged in the transition assessment process, learn the skills, and have opportunities to actively become engaged in the IEP transition planning process, the next step is to have students learn to actively attain their annual IEP transition goals. Martin et al. (1993), Field et al. (1998a), and Agran and Hughes (2008) indicated that students can be taught these skills in late elementary school and practice them through high school, and that implementing strategies to attain their annual transition goals can lead to greater student self-determination.

\section{Benefits of Students Attaining Annual Transition Goals}

As emerging CDTEI writings attest, benefits occur for students with disabilities who learn to attain their annual transition goals. Lehmann et al. (1999) found that providing opportunities at school for students to learn goal-attainment skills and to attain their goals predicted student engagement in transition planning meetings. Goff, Martin, and Thomas (2007) found that high school students who were Black and at high risk for dropping out of school were able to overcome the burden of acting White by setting and working toward attaining their postschool transition goals. Doren, Lindstrom, Zane, and Johnson (2007) interviewed numerous youth and found that those who were most successful had, among other proactive factors, clear goals that they actively worked to attain.

\section{Factors Impeding Student Engagement in Transition Planning and Education}

Although concept papers and studies have clearly articulated the benefits of active student engagement in the transition education process, several factors impede continued development. Most IEPs do not include self-determinationrelated annual transition goals that focus on teaching self-advocacy or leadership skills, goal-setting and goalattainment skills, and the identification of interests, and subsequently matching those to available jobs or educational opportunities (Wehmeyer \& Schwartz, 1998). Williams and O'Leary (2001) found that many districts do not involve their students in transition planning, nor even invite students to their secondary IEP meetings. To improve this situation, professional development and technical assistance must occur at the preservice and in-service levels. The authors recommended that federal and state improvement grants and personnel preparation funding include a mandatory focus on transition education and that state departments of education include a transition expert on their monitoring teams. 
Weidenthal and Kochhar-Bryant (2007) found that half of the special education teachers in their study did little to nothing to prepare secondary-aged students for their role in upcoming IEP meetings. They suggested that limited teacher knowledge of what to do may have contributed to not allowing student participation in transition planning. Preservice special educators ranked inadequate student involvement in transition planning as one of the major barriers to effective transition practices (Wandry et al., 2008).

The limited knowledge of professionals related to student involvement in the IEP process trickles down to students. In spite of the call that Roberts et al. (1983) issued almost 30 years ago, studies have demonstrated that many students do not know what an IEP is and have not been taught to lead the IEP meeting (Agran \& Hughes, 2008).

\section{Recommendations}

Many authors in this issue, including ourselves, predict a bright future for transition education due to the efforts during the last 35 years to infuse transition education practices into the fabric of daily secondary education practices. Perhaps most telling of this support is the fact that, today, almost $60 \%$ of states now require transition education practices to begin 2 to 3 years earlier than the federally required age of 16 (Martin, McConnell, \& Mays, 2011). We offer four recommendations so that active student involvement in the transition education assessment, transition planning, and goal-attainment process can both continue and expand.

First, federal special education rules and regulations need to explicitly address a means to increase student involvement in the IEP transition planning discussions and resulting education practices. At a minimum, the next IDEA reauthorization needs to

- ensure that transition education and planning formally begins at least by the age of 14 or earlier as deemed by the IEP team;

- ensure that transition assessments be completed at least annually and help facilitate students, parents, and professionals at the IEP meeting to select meaningful postsecondary goals and annual education, employment, and living goals;

- ensure that students are taught transition planning terminology and how to become actively involved in their IEP meeting planning discussions, and then be provided the opportunity to use their newly learned skills;

- ensure that students are taught how to attain their annual transition goals and then provided the opportunity to work weekly on attaining short-term goals leading to the attainment of the annual transition goals;

- ensure that transition education concepts are infused into general education core content classes for all students so that special education students who spend all or most of their school day in general education classes can learn essential transition skills; and

- ensure that College and Career Readiness standards address nonacademic behaviors and experiences that are associated with successful postschool employment and further education for students with disabilities.

Second, research must make a stronger connection between increased student engagement in the transition education process as well as school and postschool further education and employment outcomes for all students regardless of disability status. If this relationship can be established, it will garner attention from educators and policy makers, thus ensuring greater implementation of student-engagement practices.

Third, student engagement in transition education practices must expand to include instruction on how to be actively involved in assessment, planning, and annual transition goal attainment. Moreover, school personnel must be taught to provide opportunities to do so. With only the existing requirements in place, we fear that too many schools will only invite students to the process, and research clearly demonstrates that invitations result in nothing more than token student involvement.

Fourth, additional updated, efficient, and effective instructional materials must be developed and studied, thus enabling educators to instruct and provide opportunities for students to become involved in the transition assessment, planning, and goal-attainment processes in their general education classes. These instructional tools will provide educators the means to easily teach and infuse studentengagement opportunities for all secondary-aged students, including those with disabilities. These instructional resources will be useful to general and special educators as the number of states that require transition planning for all students continues to increase. No doubt, future CDTEI articles will be the voice to encourage and report on these endeavors.

\section{Declaration of Conflicting Interests}

The author(s) declared no potential conflicts of interest with respect to the research, authorship, and/or publication of this article.

\section{Funding}

The author(s) received no financial support for the research, authorship, and/or publication of this article.

\section{References}

Agran, M. (1987). Teaching self-control procedures to individuals who are mentally retarded. Career Development and Transition for Exceptional Individuals, 10, 107-115. doi:10.1177/088572888701000207 
Agran, M., \& Hughes, C. (2008). Asking student input: Students' opinions regarding their individualized education program involvement. Career Development and Transition for Exceptional Individuals, 31, 69-76. doi:10.1177/0885728808317657

Allen, S. K., Smith, A. C., Test, D. W., Flowers, C., \& Wood, W. M. (2001). The effects of the self-directed IEP on student participation in IEP meetings. Career Development and Transition for Exceptional Individuals, 24, 107-120. doi:10.1177/ 088572880102400202

Cobb, R. B., \& Alwell, M. (2009). Transition planning/coordinating interventions for youth with disabilities. Career Development and Transition for Exceptional Individuals, 32, 70-81. doi:10.1177/0885728809336655

Cobb, R. B., Lehmann, J., Newman-Gonchar, R., \& Alwell, M. (2009). Self-determination for students with disabilities: A narrative metasynthesis. Career Development and Transition for Exceptional Individuals, 32, 108-114. doi:10.1177/0885728809336654

Coutinho, M. J., Oswald, D. P., \& Best, A. M. (2006). Differences in outcomes for female and male students in special education. Career Development and Transition for Exceptional Individuals, 29, 48-59.

Doren, B., Lindstrom, L., Zane, C., \& Johnson, P. (2007). The role of program and alterable personal factors in postschool employment outcomes. Career Development and Transition for Exceptional Individuals, 30, 171-183. doi:10.1177/08857 288070300030601

Etscheidt, S. (2006). Issues in transition planning: Legal decisions. Career Development and Transition for Exceptional Individuals, 29, 28-47. doi:10.1177/08857288060290010201

Field, S. (1996). Historical perspective on student involvement in the transition process: Toward a vision of selfdetermination for all students. Career Development and Transition for Exceptional Individuals, 19, 169-176. doi:10.1177/088572889601900211

Field, S., Martin, J., Miller, R., Ward, M., \& Wehmeyer, M. (1998a). A practical guide for teaching self-determination. Reston, VA: Council for Exceptional Children.

Field, S., Martin, J., Miller, R., Ward, M., \& Wehmeyer, M. (1998b). Self-determination for persons with disabilities: A position statement of the Division on Career Development and Transition. Career Development and Transition for Exceptional Individuals, 21, 113-128. doi:10.1177/088572889802100202

Flannery, K. B., Newton, S., Horner, R. H., Slovic, R., Blumberg, R., \& Ard, W. R. (2000). The impact of person centered planning on the content and organization of individual supports. Career Development and Transition for Exceptional Individuals, 23, 123-137. doi:10.1177/088572880002300202

Goff, C., Martin, J. E., \& Thomas, M. K. (2007). The burden of acting white: Implications for transition. Career Development and Transition for Exceptional Individuals, 30, 134-146. doi: 10.1177/08857288070300030301

Griffin, M. M. (2011). Promoting IEP participation: Effects of interventions, considerations for CLD students. Career Devel- opment and Transition for Exceptional Individuals, 34, 153164. doi:10.1177/0885728811410561

Halpern, A. (1994). The transition of youth with disabilities to adult life: A position statement of the Division on Career Development and Transition, the council for exceptional children. Career Development and Transition for Exceptional Individuals, 17, 115-124. doi:10.1177/088572889401700201

Hill, D. S. (1983). A process for identifying the occupational interest of handicapped students using the method of pair comparisons. Career Development and Transition for Exceptional Individuals, 6, 93-99. doi:10.1177/088572888300600204

Ianacone, R. N., \& Kochhar, C. A. (1996). Great expectations: Perspectives on transition policy and practice in the context of social change. Career Development and Transition for Exceptional Individuals, 19, 177-200. doi:10.1177/088572889601900212

Johnson, D. R. (1979). Project explore: A vocational assessment model for youth with special needs. Career Development and Transition for Exceptional Individuals, 2, 40-47. doi:10.1177/088572887900200104

Johnson, J. R., \& Rusch, F. R. (1993). Secondary special education and transition services: Identification and recommendations for future research and demonstration. Career Development and Transition for Exceptional Individuals, 16, 1-18. doi:10.1177/088572889301600101

Konrad, M., \& Test, D. W. (2004). Teaching middle school students with disabilities to use an IEP template. Career Development and Transition for Exceptional Individuals, 27, 101-124. doi:10.1177/088572880402700107

Landmark, L. J., Ju, S., \& Zhang, D. (2010). Substantiated best practices in transition: Fifteen plus years later. Career Development and Transition for Exceptional Individuals, 33, 165176. doi:10.1177/0885728810376410

Lehmann, J. P., Bassett, D. S., Sands, D. J., Spencer, K., \& Gliner, J. A. (1999). Research translated into practice for increasing student involvement in transition-related activities. Career Development and Transition for Exceptional Individuals, 22, 3-19. doi:10.1177/088572889902200102

Martin, J. E., Greene, B. A., \& Borland, B. J. (2004). Secondary students' involvement in their IEP meetings: Administrators' perceptions. Career Development and Transition for Exceptional Individuals, 27, 177-188. doi:10.1177/088572880402700204

Martin, J. E., Marshall, L. H., \& Maxson, L. L. (1993). Transition policy: Infusing self-determination and self-advocacy into transition programs. Career Development and Transition for Exceptional Individuals, 16, 53-61. doi:10.1177/088572889301600105

Martin, J. E., Marshall, L. H., Maxson, L. M., \& Jerman, P. L. (1996). The self-directed IEP. Longmont, CO: Sopris West.

Martin, J. E., McConnell, A., \& Mays, B. (2011, October). When transition education must begin: What the states are doing. Paper presentation at the 16th Division on Career Development and Transition Conference, Kansas, MO.

Martin, J. E., Van Dycke, J., D’Ottavio, M., \& Nickerson, K. (2007). Student-directed summary of performance: Increasing student 
and family involvement in the transition planning process. Career Development and Transition for Exceptional Individuals, 30, 13-26. doi:10.1177/08857288070300010101

Mason, C. Y., McGahee-Kovac, M., Johnson, L., \& Stillerman, S. (2002). Implementing student-led IEPs: Student participation and student and teacher reactions. Career Development and Transition for Exceptional Individuals, 25, 171-192. doi:10.1177/088572880202500206

Mithaug, D. E., Martin, J. E., \& Agran, M. (1987). Adaptability Instruction: The goal of transitional programming. Exceptional Children, 56, 500-505.

Morningstar, M. E., Frey, B. B., Noonan, P. M., Ng, J., ClavennaDeane, B., Graves, P., \& Williams-Diehm, K. (2010). A preliminary investigation of the relationships of transition preparation and self-determination for students with disabilities in postsecondary educational settings. Career Development and Transition for Exceptional Individuals, 33, 80-94. doi:10.1177/0885728809356568

Morningstar, M. E., \& Liss, J. M. (2008). A preliminary investigation of how states are responding to the transition assessment requirements under IDEIA 2004. Career Development and Transition for Exceptional Individuals, 31, 48-55. doi:10.1177/0885728807313776

Palmer, S. B., Wehmeyer, M. L., Shogren, K. A., Williams-Diehm, K. L., \& Soukup, J. H. (2012). An evaluation of the beyond high school model on the self-determination of students with intellectual disability. Career Development and Transition for Exceptional Individuals, 35, 76-84. doi:10.1177/0885728811432165

Powers, K. M., Gil-Kashiwabara, E., Geenen, S. J., Powers, L. E., Balandran, J., \& Palmer, C. (2005). Mandates and effective transition planning practices reflected in IEPs. Career Development and Transition for Exceptional Individuals, 28, 47-59. doi:10.1177/08857288050280010701

Powers, L. E., Turner, A., Westwood, D., Matuszewski, J., Wilson, R., \& Phillips, A. (2001). Take charge for the future: A controlled field-test of a model to promote student involvement in transition planning. Career Development and Transition for Exceptional Individuals, 24, 89-104. doi:10.1177/088572880102400107

Repetto, J. B., Horky, S. C., Miney, A., Reiss, J., Saidi, A., Wolcott, L., \& Jaress, J. M. (2012). Expanding transition to address the needs of students with invisible chronic illness. Career Development and Transition for Exceptional Individuals, 35, 4-13. doi: $10.1177 / 0885728811423653$

Repetto, J. B., Webb, K. W., Garvan, C. W., \& Washington, T. (2002). Connecting student outcomes with transition practices in Florida. Career Development and Transition for Exceptional Individuals, 25, 123-139. doi:10.1177/088572880202500203

Roberts, S., Doty, D., Santleben, S., \& Tang, T. (1983). A model for vocational assessment of handicapped students. Career Development and Transition for Exceptional Individuals, 6, 100-110. doi:10.1177/088572888300600205

Rusch, F. R., Hughes, C., Agran, M., Martin, J. E., \& Johnson, J. R. (2009). Toward self-directed learning, post-high school placement, and coordinated support: Constructing new transition bridges to adult life. Career Development and Transition for Exceptional Individuals, 32, 53-59. doi: 10.1177/ 0885728809332628

Sitlington, P. L. (1996). Transition assessment - Where have we been and where should we be going? Career Development and Transition for Exceptional Individuals, 19, 159-168. doi:10.1177/088572889601900210

Sitlington, P. L., Neubert, D. A., \& Leconte, P. J. (1997). Transition assessment: The position of the Division on Career Development and Transition. Career Development and Transition for Exceptional Individuals, 20, 69-79. doi:10.1177/088572889702000106

Sitlington, P. L., \& Wimmer, D. (1978). Vocational assessment techniques for the handicapped adolescent. Career Development and Transition for Exceptional Individuals, 1, 74-87. doi:10.1177/088572887800100202

Steere, D. E., Pancsofar, E., Wood, R., \& Hecimovic, A. (1990). Principles in shared responsibility. Career Development and Transition for Exceptional Individuals, 13, 143-153. doi:10.1177/088572889001300206

Test, D. W., Mazzotti, V. L., Mustian, A. L., Fowler, C. H., Kortering, L., \& Kohler, P. (2009). Evidence-based secondary transition predictors for improving postschool outcomes for students with disabilities. Career Development for Exceptional Individuals, 32, 160-181.

Trainor, A. A., Lindstrom, L., Simon-Burroughs, M., Martin, J. E., \& Sorrells, A. M. (2008). From marginalized to maximized opportunities for diverse youths with disabilities: A position paper on the Division on Career Development and Transition. Career Development and Transition for Exceptional Individuals, 31, 56-64. doi:10.1177/0885728807313777

Valenzuela, R. L., \& Martin, J. E. (2005). Self-directed IEP: Bridging values of diverse cultures and secondary education. Career Development and Transition for Exceptional Individuals, 28, 4-14. doi:10.1177/0885728805028 0010301

Van Reusen, A. K., Bos, C. S., Schumaker, J. B., \& Deshler, D. D. (1987). The education planning strategy. Lawrence, KS: Edge Enterprises.

Wandry, D. L., Webb, K. W., Williams, J. M., Bassett, D. S., Asselin, S. B., \& Hutchinson, S. R. (2008). Teacher candidates' perceptions of barriers to effective transition programming. Career Development and Transition for Exceptional Individuals, 31, 14-25. doi:10.1177/0885728808315391

Wehmeyer, M. L. (1993). Perceptual and psychological factors in career decision-making of adolescents with and without cognitive disabilities. Career Development and Transition for Exceptional Individuals, 16, 135-146. doi:10.1177/088572889301600203

Wehmeyer, M. L., \& Lawrence, M. (1995). Whose future is it anyway? Promoting student involvement in transition planning. Career Development and Transition for Exceptional Individuals, 18, 69-83. doi:10.1177/088572889501800202 
Wehmeyer, M. L., Palmer, S. B., Agran, M., Mithaug, D. E., \& Martin, J. E. (2000). Promoting causal agency: The self-determined learning model of instruction. Exceptional Children, 66, 439-453.

Wehmeyer, M. L., Palmer, S. F., Lee, Y., Williams-Diehm, K., \& Shogren, K. (2011). Randomized-trial evaluation of the effect of Whose Future Is It Anyway? On self-determination. Career Development and Transition for Exceptional Individuals, 34, 45-56. doi:10.1177/0885728810383559

Wehmeyer, M. L., \& Schwartz, M. (1998). The self determination focus of transition goals for students with mental retardation. Career Development and Transition for Exceptional Individuals, 20, 75-86. doi:10.1177/088572889802100107

Weidenthal, C., \& Kochhar-Bryant, C. (2007). An investigation of transition practices for middle school youth. Career Develop- ment and Transition for Exceptional Individuals, 30, 147-157. doi:10.1177/08857288070300030401

Williams, J. M., \& O'Leary, E. (2001). What we've learned and where we go from here. Career Development and Transition for Exceptional Individuals, 24, 51-71. doi:10.1177/088572880102 400105

Woods, L. L., Sylvester, L., \& Martin, J. E. (2010). Studentdirected transition planning: Increasing student knowledge and self-efficacy in the transition planning process. Career Development and Transition for Exceptional Individuals, 33, 106-114. doi:10.1177/0885728810368056

Zhang, D., Ivester, J. G., Chen, L. J., \& Katsiyannis, A. (2005). Perspectives on transition practices. Career Development and Transition for Exceptional Individuals, 28, 15-25. doi:10.117 7/08857288050280010401 